\title{
Reflexões sobre atitude, comportamento e Oftalmologia
}

$\mathbf{P}$ or atitude compreende-se uma maneira organizada e coerente de pensar, sentir e reagir em relação a grupos, questões, outros seres humanos ou, mais especificamente, a acontecimentos ocorridos em nosso meio circundante ${ }^{(1-2)}$. Trata-se de um dos conceitos fundamentais da psicologia social, por fazer a junção entre a opinião (comportamento mental e verbal) e a conduta (comportamento ativo), indicando o que interiormente estamos dispostos a fazer, ou seja, a predisposição que temos de reagir a estímulos de maneira positiva ou negativa ${ }^{(2)}$.

O comportamento refere-se ao conjunto organizado das operações selecionadas em função das informações recebidas do ambiente através do qual o indivíduo integra suas tendências ${ }^{(3)}$. Ou seja, designa a mudança, o movimento ou reação de qualquer entidade ou sistema em relação a seu ambiente ou situação $^{(2)}$.

A Oftalmologia é uma das especialidades médicas mais desejadas e concorridas nos concursos de residência médica e de especialização, permitindo aos que a abraçam como profissão desfrutar de alto nível de satisfação intelectual e emocional ${ }^{(4.5)}$. No entanto, a cada ano, mais da metade dos médicos que a abraçam não conseguem obter treinamento em serviço credenciado pelo CBO/MEC. E já representamos uma proporção acima daquela preconizada pela Organização Mundial da Saúde que é de um oftalmologista para cada 20 mil habitantes ${ }^{(6)}$. Nesta área, somos os profissionais mais preparados e habilitados para colocar a ciência e o conhecimento (de ponta) a serviço da sociedade. No entanto, precisamos de nossa união para convencer a sociedade e o governo da necessidade da implantação urgente, na rede de saúde pública, do atendimento oftalmológico inserido num Programa Nacional de Saúde Ocular que inclua, inicialmente, no mínimo, acesso facilitado do paciente ao exame refratométrico e aos óculos. Para tanto, é necessário implantar consultórios oftalmológicos ou unidades de refração na rede de saúde pública, e conseqüentemente, a contratação de oftalmologistas e a elaboração de um Programa Nacional de Saúde Ocular sem o que não se conseguirá alterar o grave quadro de deficiência visual que atinge adultos e crianças no Brasil. Ou não é verdade que metade da cegueira em pessoas com mais de 50 anos na cidade de São Paulo se dá por falta de óculos? Ou não é verdade que mais de sessenta por cento dos problemas de visão são evitáveis por meio de prevenção ou de tratamentos já disponíveis em consultórios, mas ainda assim, a exclusão social continua condenando à cegueira uma grande parte dos brasileiros menos favorecidos economicamente. Ou não são estes fatos que expõem o abismo existente hoje entre o médico oftalmologista e o paciente e que servem de argumento para justificar o aparecimento de outro profissional para preenchê-lo? O médico oftalmologista quer e deve atender à população brasileira. E só não o faz porque este atendimento não faz parte da prioridade dos governos federal, estadual e municipal.

Em termos psicológicos, atitude é um conceito amplo que designa a orientação do nosso pensamento, das nossas disposições profundas e do nosso estado de espírito diante de determinado objeto (situação, idéia, pessoa); ou seja, atitude é uma disposição interna que orienta a nossa conduta diante dos fatos e acontecimentos da vida, sejam eles reais (concretos) ou simbólicos ${ }^{(7)}$. O aspecto tríplice de uma atitude se compõe de caráter cognitivo (crenças, valores, julgamentos); caráter afetivo (sentimentos favoráveis ou desfavoráveis) e caráter conativo ou comportamental (tendência de ação) $)^{(7)}$. Os processos condizentes à aquisição de atitudes se dão pelos resultados de nossa própria experiência; nossas tendências e preconceitos perceptivos; nossas observações das reações de uma pessoa a uma situação específica; e da nossa observação dos resultados das experiências de outra pessoa ${ }^{(2)}$. Como vimos, atitude é intenção e comportamento é ação. Atitude é uma intenção de se comportar de certa maneira, a intenção pode ou não ser consumada, dependendo da situação ou das circunstâncias. Mudanças nas "atitudes" de uma pessoa podem demorar muito para causar mudanças de "comportamento" que, em alguns casos, podem nem chegar a ocorrer ${ }^{(2)}$. As 
tentativas de modificar ou substituir "atitudes" assentam nos mesmos princípios de aprendizagem, sendo muito mais difícil mudar ou esquecer "atitudes" do que aprendê-las ${ }^{(1-2)}$.

Vivemos em um mundo de causas e efeitos. Algumas coisas acontecem. Outras fazemos com que aconteçam. Como resultado destes acontecimentos, outras coisas são ainda afetadas. A vida é uma série de eventos interligados. Seu trabalho influencia esta série de eventos de modo que aconteçam coisas que contribuam para as metas e objetivos da organização. Também, podemos impedir que situações não desejadas ocorram. A mudança é uma constante na vida e nas empresas. O objetivo de cada profissional é fazer com que as mudanças desejadas ocorram de forma ordenada ${ }^{(7)}$. As pessoas buscam uma sensação de equilíbrio entre suas atitudes e comportamentos com o objetivo de reduzir seus conflitos internos quando enfrentam um choque entre seus pensamentos e seus atos ${ }^{(8)}$. Atitudes são constatações, favoráveis ou desfavoráveis, em relação a objetos, pessoas, eventos ou instituições. O plano cognitivo da atitude está relacionado ao conhecimento consciente de determinado fato. $\mathrm{O}$ componente afetivo corresponde ao caráter emocional ou sentimental de uma atitude. A vertente conativa está relacionada à intenção de comportarse de determinada maneira com relação a alguém, alguma coisa ou instituição ${ }^{(8)}$. Para melhor compreensão, tomemos o exemplo a seguir. "Inseridas na realidade atual se destacam as contribuições das COOESOs, catequizando cada oftalmologista para cooperar-se e incorporar-se à batalha coletiva pelo exercício da Oftalmologia com mais honra e dignidade, por remuneração mínima mais justa e a favor da saúde ocular do brasileiro. Uns, se cooperam, e outros, impiedosamente, as criticam. Os que se cooperam o fazem por consciência do benefício potencial que essas parcerias representam aos seus exercícios profissionais. Os que as criticam ou não se cooperam, parecem não perceber que dão força a muitos "colegas" para continuarem contribuindo para minar seus campos profissionais. Até que um dia, um ou vários deles são vitimados por mais um destes tantos "pacotes cirúrgicos". Para os vitimados, neste momento, abre-se a porta que dá acesso ao caráter emocional da atitude: eles sentem o mal a que estavam se sujeitando e podem decidir agir, mudando seus comportamentos, quiçá, cooperando-se". As pessoas acham que atitude é ação. Todavia, atitude é racionalizar, sentir e externar. A atitude não é um processo exógeno. É algo interno, que deve correr de dentro para fora. E entre a conscientização e a ação, necessariamente deve estar presente o sentimento, como elo de ligação. Ou você sente, ou você não muda ${ }^{(8)}$... Se você sente..., experimente trocar a COOESO no exemplo acima, por CBO, SBO, CRM, AMB, etc.

\section{Clínicas da Faculdade de Medicina da Universidade de São Paulo - USP - São Paulo (SP), Brasil}

\section{REFERÊNCIAS}

1. Kardec A. A Obsessão. 3a ed. São Paulo, O Clarim, 1978.

2. Gregório SB. Atitude e Comportamento [texto na Internet]. [citado 200812 Jan. 12]. Disponível em http://www.ceismael.com.br/ artigo/ artigo057.htm

3. Ávila FB. Pequena enciclopédia de moral e civismo. 2a ed., Rio de Janeiro: Fename. Ministério da Educação e Cultura; 1972.

4. Delgado AC, Sena M, Corbera JC, Ventura LO. Perfil de 80 Pós-graduandos em Oftalmologia do Estado de Pernambuco, de 1998 a 2001. Rev Bras Oftalmol. 2002; 61(3): 204-9.

5. Alves MR, Nakashima AF. Motivações e percepções de médicos residentes em relação à escolha da carreira em Oftalmologia. Rev Bras Oftalmol. 2003; 62(11):776-81.

6. Conselho Brasileiro de Oftalmologia. Censo 2001: Distribuição dos oftalmologistas por estado. São Paulo: CBO; 2001.

7. Hilsdorf C. Atitudes vencedoras. 8a ed. São Paulo, Senac; 2005.

8. Coelho T. Atitude [Internet]. [citado 2008 Jan 12]. Disponível em: http://www.annex.com.br/artigos/tomcoelho5.asp 